\title{
The Correlation of SKA2 with Cortisol, IL-1 $\beta$ and Anxiety in Pregnant Women with the Risk of Preterm Delivery
}

\author{
Janat ljabi', Reza Afrisham², Hemen Moradi-Sardareh², Parisa Roozehdar ${ }^{3}$, \\ Fatemeh Seifi ${ }^{4}$, and Roghayeh $\mathrm{ljabi}^{4 凶}$ \\ ${ }^{1}$ Department of Hematology, School of Allied Health, Iran University of Medical Sciences, Tehran, Iran \\ ${ }^{2}$ Department of Clinical Biochemistry, Faculty of Medicine, Tehran University of Medical Sciences, Tehran, Iran \\ ${ }^{3}$ Department of Medical Veterinary, Azad University, Garmsar Branch, Garmsar, Iran \\ ${ }^{4}$ Counseling and Reproductive Health Research Centre, Golestan University of Medical Sciences, Gorgan, Iran
}

Objective The association between preterm birth (PTB), Spindle and Kinetochore Associated Complex Subunit 2 gene (SKA2), cortisol and anxiety have been shown, but in this study, we aimed to clarify whether the expression of the SKA2 gene plays a role in interleukin$1 \beta$ (IL-1 $\beta$ ) level since increasing level of IL- $1 \beta$ is linked with PTB.

Methods The case-control study was conducted on 49 and 51 women with preterm and term delivery, respectively. The score of anxiety was ranked according to the Spielberger state trait Anxiety Inventory. The concentration of cortisol and IL- $1 \beta$ was determined by the ELISA method. The expression of SKA2 gene was assessed by the quantitative real time real time polymerase chain reaction (qRT-PCR). The western blot analysis was also performed to confirm the expression of SKA2 at the levels of protein.

Results The results showed that the gene/protein expression of SKA2, the concentrations of cortisol and IL- $1 \beta$ were significantly higher in the preterm than the term group. In the preterm group, the expression of SKA2 was positively correlated to the other factors including cortisol, IL-1 $\beta$, and the degree of anxiety.

Conclusion Our findings suggest that the expression of SKA2 was correlated positively to the levels of cortisol, IL-1 $\beta$ and the rate of anxiety in women with PTB.

Psychiatry Investig 2020;17(5):387-394

Key Words Anxiety, Cortisol, IL-1 $\beta$, Premature birth, Pregnancy, SKA2.

\section{INTRODUCTION}

The preterm birth (PTB) is defined as birth occurring before 37 completed weeks of gestation, which accounts for two-thirds of infant death worldwide. ${ }^{1}$ The prevalence of preterm delivery varies over the world as the most incidence rate belongs to countries with poor socio-economic conditions. The prevalence of premature birth is inversely associated with the socioeconomic status of countries. The cost of care is very high for premature infants. ${ }^{2}$

Preterm delivery has multifactorial etiology in which vari-

Received: May 19, 2019 Revised: October 21, 2019

Accepted: December 18, 2019

$\triangle$ Correspondence: Roghayeh Ijabi, MSc, PhD

Counseling and Reproductive Health Research Centre, Golestan University of

Medical Sciences, Shast Kola Road, Gorgan, Iran

Tel: +981732426900, Fax: +981732455171, E-mail: R.ijabi@goums.ac.ir

(a) This is an Open Access article distributed under the terms of the Creative Commons Attribution Non-Commercial License (https://creativecommons.org/licenses/bync/4.0) which permits unrestricted non-commercial use, distribution, and reproduction in any medium, provided the original work is properly cited. ous factors synergistically result in premature birth in pregnant women include genetic, environmental and hormonal factors. It has been reported that placental Hypothalamic-PituitaryAdrenal (HPA) axis plays a significant role in the development of preterm delivery. ${ }^{3-5}$ The highest concentration of corticotropin-Releasing Hormone (CRH) is secreted by pituitary and placenta of pregnant women just near delivery. ${ }^{3-5}$ Scientific reports also show that cortisol is produced at a significant level in the third quarter, and it would be increased as the delivery time approaches. ${ }^{6}$ Placental CRH is different from maternal $\mathrm{CRH}$ and not affected by the negative feedback of adrenal glucocorticoids. The increased production of cortisol induces the secretion of placental CRH which, in turn, leads to an increase in the concentration of cortisol by affecting the fetal adrenal gland. ${ }^{3-5}$

A growing body of evidence proves that cortisol levels are also increased during anxiety. ${ }^{7-9}$ Anxiety influences maternal adrenal glands through an increase in maternal CRH, followed by an increment in cortisol level, eventually leading to increased 
fetal cortisol mediated by cortisol-induced placental CRH. ${ }^{10,11}$ Some studies have suggested that placental $\mathrm{CRH}$ is probably related to stress ${ }^{12-14}$ and there is a significant relationship between anxieties with preterm delivery. ${ }^{7-9}$

As mentioned above, high levels of $\mathrm{CRH}$ lead to increased cortisol production from the adrenal gland of the mother and the fetus, as well as increased the production of steroids. Higher cortisol levels may result in changes in other hormones. It is approved that placental CRH increase the production of estrogen. ${ }^{15}$ There is a hypothesis suggesting that the increased estrogen levels may alter the homeostasis, change the progesterone receptors, and lead to delivery. Progesterone is considered as a tranquilizer factor in the uterus which is sometimes prescribed as a drug for the management of preterm delivery. ${ }^{16-20}$ $\mathrm{CRH}$ also increases the contraction of the uterus by increasing the level of prostaglandin. ${ }^{19}$ Therefore, $\mathrm{CRH}$ and cortisol are used as placental clock. ${ }^{3}$

Also, an increase in the level of cortisol for the long-term period can induce inflammatory factors including IL-1 $\beta ;^{21,22}$ and IL- $1 \beta$ which is indirectly linked with preterm delivery by increasing the levels of Toll-like receptors (TLRs). On the other hand, the lack of TLRs is correlated with delayed or post-term delivery. ${ }^{23-25}$ Cortisol and IL- $1 \beta$ have a synergistic effect on the preterm delivery; it has been shown that cortisol can cause collagen atrophy and Premature Rupture of the Membranes (PROM), moreover, increased IL- $1 \beta$ results in the elevation of metalloproteinases, collagen deformation, and PROM..$^{26-28}$

Recent studies demonstrated that kinetochore associated complex subunit 2 (SKA2) gene could regulate the secretion of cortisol via chaperoning glucocorticoid receptors in order to transport them from the cytoplasm into the nucleus ${ }^{29}$ and the SKA2 gene expression is associated with the increase in cortisol level. ${ }^{29}$ Also, an association between anxiety and the expression of SKA2 has been reported in some studies, ${ }^{30}$ and in another study there is a relationship between PTB and increasing cortisol level and SKA2 gene single-nucleotide polymorphism (SNP) (NC_000017.11: g.59110368G>A) which supposed as predictive PTB biomarker in pregnant women. ${ }^{31}$

Regarding the effect of cortisol and IL- $1 \beta$ on the risk of premature birth and the impact of the SKA2 expression on the regulation of cortisol; we decided to investigate the role of the SKA2 expression on IL-1 $\beta$ in the susceptibility of premature birth in pregnant women. Hence, the question is whether the expression of the SKA2 gene plays a role in preterm delivery through the changes in the degree of anxiety, as well as the expression of cortisol and IL-1 $\beta$. In some researches have shown that IL-1 $\beta$ could possibly serve as a marker for preterm delivery $^{32,33}$ but in the current study, we evaluated the relationship of SKA2 with IL-1 $\beta$ in preterm delivery for the first time.

\section{METHODS}

\section{Ethical approval}

The study was approved by the ethics committee of the Golestan University of Medical Science, Iran (NO: EC/IR.GOUMS. rec. 1394.79). Written informed consent was obtained from all pregnant women.

\section{Study design and the collection of samples}

An analytical case-control study was carried out in pregnant women who referred to Shariati and Arash Hospitals, affiliated with Tehran University of Medical School (TUMS), for giving birth. Sample collection was performed between Feb 2014 and Feb 2017. A total number of 100 pregnant women were divided into two groups. The experimental group consisted of 49 pregnant women with preterm delivery who gave birth during 34-37 weeks of pregnancy. The control group included 51 pregnant women with term delivery. Both groups of pregnant women were adjusted considering the confounding factors such as age, history of conception (1-3 times), academic education, and their employment. The inclusion criteria for the selection of pregnant women were age range between 18-40 years, singleton pregnancy, medium family income, and routine serial weighing during pregnancy. The exclusion criteria were depression, mental disorders leading to hospitalization, cervical failure, hypertension, preeclampsia, acute fatty liver, vaginal infections, pyelonephritis, antepartum hemorrhage, inability of mother to gain weight during the gestation period, placental abruption, placenta Previa, low maternal weight as a cause of intrauterine growth restriction (IUGR), oligohydramnios, use of tobacco, alcohol, and cocaine during pregnancy, cardiovascular diseases, diabetes, and kidney failure. By referring to the patient's file, we extracted the information such as psychiatric screening that was evaluated every three months during pregnancy and recorded in the file, and even the screening for diabetes, hypertension and acute fatty liver etc. using the diagnostic methods. The rest of information was got from interviews.

\section{Evaluation of serum cortisol and IL-1 $\beta$}

About $10 \mathrm{~mL}$ of blood samples were collected from all individuals after 24 hours of delivery at 8 A.M. while pregnant women were fasting (about 10 hours). Each blood sample was aliquoted into two parts. One part was specified for the isolation of serum and another for the isolation of peripheral blood mononuclear cells (PBMCs). To separate serum from the whole blood sample, tubes were immediately centrifuged at 3,500 rpm for 10 minutes, and the obtained sera were stored at $-80^{\circ} \mathrm{C}$ until the measurements. The concentrations of IL- $1 \beta$ and cortisol were measured using the ELISA commercial kits [for IL- 
$1 \beta$ (Quantikine HS ELISA Kit HSLB00D, Minneapolis, MI, USA) with an intra-assay coefficient of variation $(\mathrm{CV})=2.4 \%$, inter-assay $\% \mathrm{CV}=6.3 \%$ and for cortisol (IBL international, Hamburg, Germany) with an intra-assay $\mathrm{CV}=2.57 \%$, inter-assay $\% \mathrm{CV}=3.41 \%]$, and finally the absorbance of the samples $(450 \mathrm{~nm})$ was read with an ELISA Reader (Bio-Tek ELX800, Winooski, VT, USA). All the tests were carried out as duplicate measurements.

\section{Western blot}

To extract the total cellular protein contents, $100 \mathrm{~mL}$ of the blood samples were homogenized in $1 \mathrm{~mL}$ ice-cold extraction buffer (PBS). After the incubation for $20 \mathrm{~min}$ at $4^{\circ} \mathrm{C}$, two centrifugation steps were performed at $4^{\circ} \mathrm{C}$ at $14,000 \times \mathrm{rpm}$ for $20 \mathrm{~min}$ to remove cell debris. Afterward, $20 \mu \mathrm{g}$ of the extracted proteins were loaded in each lane on $7.5 \%(\mathrm{w} / \mathrm{v})$ polyacrylamide gel and then transferred to a PVDF membrane (Amersham Biosciences, Freiburg, Germany). After the incubation in blocking solution ( $5 \%$ skim milk powder in $1 \times \mathrm{PBS}$ ), the membrane was incubated with primary antibodies against SKA2 (Santa Cruz Biotechnology, Santa Cruz, CA, USA) at a 1:300 dilution and $\beta$-actin at a 1:1,000 dilution (as a loading control) at $4^{\circ} \mathrm{C}$ overnight. After washing the membrane, it was probed with anti-rabbit IgG-HRP (Santa Cruz Biotechnology) at a 1:3,000 dilutions for 1-2 $\mathrm{h}$ at room temperature for 3-5 hours. The bound proteins were visualized by chemiluminescence using enhanced electrochemiluminecence (ECL) reagents and subsequent autoradiography. Densitometry analysis was performed using scanning immunoblots and quantitating protein bands using ImageJ software (National Institutes of Health, imagej. nih.gov/ij).

\section{RNA extraction and reverse transcription}

About $5 \mathrm{~mL}$ of whole blood was collected and poured into two K2 ethylenediaminetetraacetic acid (EDTA) tubes. The tubes were stored at $-20^{\circ} \mathrm{C}$. The EDTA tubes were transferred into a $50 \mathrm{~mL}$ polypropylene conical centrifuge tube, and then RBC Lysis Buffer was added until the volume brought to $45 \mathrm{~mL}$. The mixtures were left at room temperature for 10 minutes. Then, 1,200 $\mu \mathrm{L}$ of TRIzol solution was added to each tube. The extracted RNA was assessed by the measurement of the absorbance at $260 \mathrm{~nm}$ using NanoDrop ND-1000 (NanoDrop Technologies, Montchanin, DE, USA). After mixing and centrifugation, the extracted RNA was stored on ice. Next, $5 \mu$ g of the total RNA was added to $1 \mu \mathrm{L}$ Random Hexamer primer, and then the volume was brought to $12 \mu \mathrm{L}$ with distilled water according to the Ampliqon Kit (Ampliqon, Odense, Denmark). RNA template was mixed, centrifuged, and incubated at $65^{\circ} \mathrm{C}$ for 5 minutes and immediately placed on ice. In the next step, $4 \mu \mathrm{L}$ of $5 \mathrm{X}$ reaction buffer, $1 \mu \mathrm{L}$ of Ribolick RNase Inhibitor,
$2 \mu \mathrm{L}$ of $10 \mathrm{Mm}$ dNTP Mix, and $1 \mathrm{ML}$ of Revert Aid M-MuLVRT $(200 \mathrm{U} / \mu \mathrm{L})$ were added to the final product, and the volume was brought to $20 \mu \mathrm{L}$ with distilled water (Ampliqon Kit Denmark).

\section{Quantitative real-time PCR}

The expression of SKA2 gene was measured by real-time polymerase chain reaction. In this method, $5 \mu \mathrm{L}$ of Master Mix SyberGreen $(10 \mu \mathrm{mol} / \mathrm{L})$ was added to $0.5 \mu \mathrm{L}$ of the forward primer (SKA2) with the sequence of 5'-GCCCAACAGGAAAATGTGTC-3' and $0.5 \mu \mathrm{L}$ of reverse primers with the sequence of 5'-CCGCCTCCATGTTGAATAGT-3'. The same amount of Master Mix SyberGreen was added to $0.5 \mu \mathrm{L}$ of the forward primer (GAPDH) with the sequence of 5'-GAAGGTGAAGGTCGGAGTC-3' and $0.5 \mu \mathrm{L}$ of the reverse primer with the sequence of 5'-GAAGATGGTGATGGGATTTC-3'. Next, $0.8 \mu \mathrm{L}$ of complementary DNA (cDNA) was added and the volume was brought to $10 \mu \mathrm{L}$ with distilled water. The PCR was performed by the StepOnePlus Real-Time PCR System (Applied Biosystems, Foster City, CA, USA). The threshold cycle (CT) is defined as a fraction of the cycle at which the fluorescence is emitted from denatured DNA. The PCR products were identified using ethidium bromide with electrophoresis on $1.2 \%$ agarose gel.

\section{Anxiety detection}

In this study, the anxiety scores were examined by Spilberger Inventory. About 40 items in two sections of the state and trait Anxiety Inventory were used. Items in a four-point Likert scale were evaluated. Each item was categorized from 1 to 4 followed by the rate of overall scores which was varied from 20 to 80 (Cronbach alpha 0.94 and 0.87 , respectively). ${ }^{34}$

\section{Statistical analysis}

Baseline data and demographic characteristics of participants were compared using chi-square tests. The independent t-test was applied to compare differences between term and preterm groups. Pearson correlation coefficient was separately calculated between the expression of the SKA2 gene and the concentrations cortisol and IL- $1 \beta$, as well as the score of the state and trait anxiety. All of the statistical analyses were performed by the SPSS software, version 21 (IBM Corp., Armonk, NY, USA). The p-value of less than 0.05 was considered statistically significant.

\section{RESULTS}

The comparison of the relative gene expression of SKA2, as well as the levels of cortisol and IL-1 $\beta$, and last menstrual period (LMP), baby weight, and APGAR score between the two 
preterm and term groups, showed significant differences. The anxiety scores (trait and state) in preterm group slightly more than term group but not significant (Table 1, Figure 1).

As shown in Table 2 , there is a significantly positive correlation between the increase in the expression of SKA2 gene and cortisol, IL-1 $\beta$, and state anxiety, as well as $S K A 2$ expression has significant negative correlation with LMP, baby weight, and APGAR. There is also a significant relationship between increased levels of cortisol and the concentration of IL-1 $\beta$, as well as the score of state and trait anxiety. An increment in the levels of IL-1 $\beta$ was also significantly associated with state and trait anxiety. There is significantly negative correlation between the increase of both cortisol and IL-1 $\beta$ levels with LMP, baby weight, and APGAR.

Table 1. The comparison of all variables in preterm and term delivery groups

\begin{tabular}{lllccr}
\hline \multicolumn{1}{c}{ Variables } & Groups & $\mathrm{N}$ & \multicolumn{1}{c}{ Mean } & SD & p-value \\
\hline Age (years) & Preterm & 49 & 25.21 & 0.29 & 0.682 \\
& Term & 51 & 26.37 & 0.34 & \\
SKA2 & Preterm & 49 & 2.9167 & 0.41706 & $<0.001$ \\
& Term & 51 & 1.7016 & 0.52210 & \\
Cortisol (nmol/L) & Preterm & 44 & 270.7045 & 73.55320 & $<0.001$ \\
& Term & 42 & 207.3333 & 53.37610 & \\
IL-1ß (pg/mL) & Preterm & 49 & 2.5316 & 0.53172 & 0.046 \\
& Term & 51 & 2.3112 & 0.55673 & \\
Trait anxiety & Preterm & 49 & 50.4490 & 13.85349 & 0.956 \\
& Term & 51 & 50.2941 & 14.23137 & \\
State anxiety & Preterm & 49 & 50.8163 & 14.54400 & 0.964 \\
& Term & 51 & 49.1176 & 14.75757 & \\
\hline
\end{tabular}

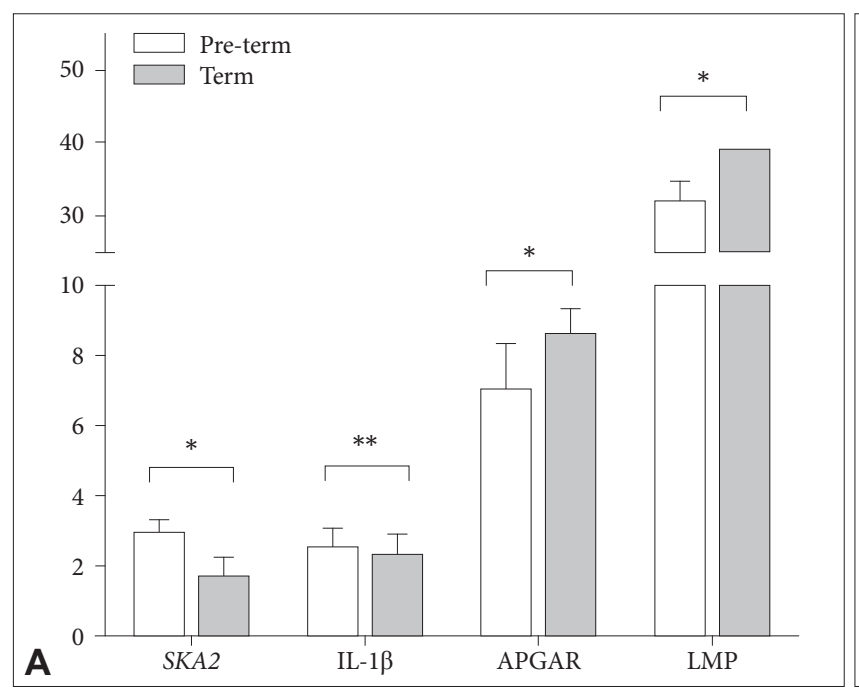

Figure 1. The comparison of all variables (A. SKA2, IL-1B, APGAR and LMP as well as B. Baby weight, cortisol, Trait anxiety and State anxiety) between preterm and term groups. All variables except for both parameter of anxiety showed a significant difference between the term and preterm groups. Data are presented as the mean $\pm S D$ (preterm $N=49$, term $N=51$ ) and were analyzed by independent sample $t$ test. ${ }^{*} p<0.0001,{ }^{* *} p<0.05$. Units: nmol/L for cortisol, $\mathrm{pg} / \mathrm{mL}$ for $\mathrm{IL}-1 \beta$, weeks for $\mathrm{LMP}$, grams for body weight.
According to Table 3, it was shown that parallel with an increase in the expression of SKA2 gene in the preterm group, the rate of anxiety levels, as well as the levels of IL-1 $\beta$ and cortisol was heightened. Accordingly, an increase in the level of cortisol is significantly associated with the increase in the concentration of IL-1 $\beta$ and the score of state and trait anxiety. Notably, increased level of IL-1 $\beta$ is significantly correlated with the increase in the score of state and trait anxiety. The present data demonstrate that the increase of SKA2 expression, cortisol, IL$1 \beta$, and anxiety scores significantly negatively correlated with LMP, baby weight, and APGAR

As shown in Table 4, in term group expression of the SKA2 gene has not significant correlation with the concentration of cortisol and IL-1 $\beta$, as well as the score of trait anxiety. An increase in the expression of SKA2 leads to a reduction in the levels of factors which were mentioned earlier. On the other hand, parallel with the increase in cortisol, a significant increase was observed in the level of IL-1 $\beta$ and the degree of state anxiety and trait anxiety. An increase in the level of IL-1 $\beta$ is also significantly correlated with the increase in state and trait anxiety.

As indicated in Figure 2 and Table 5, the western blot analysis showed that the level of SKA2 protein was significantly higher $(\mathrm{p}=0.008)$ in the preterm group compared with the term group.

\section{DISCUSSION}

There is some evidence on the association of anxiety and premature birth. However, causing why anxiety lead to preterm delivery is not clear, but the rate of anxiety is high in pregnant women, causing many adverse effects such as hyperten- 
Table 2. Correlation analysis between SKA2 expression and other variables in all participants

\begin{tabular}{|c|c|c|c|c|c|c|c|}
\hline SKA2 & Cortisol & IL-1 $\beta$ & Latent anxiety & Apparent anxiety & LMP & Baby weight & APGAR \\
\hline \multirow[t]{14}{*}{ SKA2 } & $\mathrm{R}=0.551$ & $\mathrm{R}=0.266$ & NS & $\mathrm{R}=0.202$ & $\mathrm{R}=-0.765$ & $\mathrm{R}=-0.744$ & $\mathrm{R}=-0.571$ \\
\hline & $\mathrm{p}<0.001$ & $\mathrm{p}=0.008$ & & $\mathrm{p}=0.040$ & $\mathrm{p}<0.001$ & $\mathrm{p}<0.001$ & $\mathrm{p}<0.001$ \\
\hline & Cortisol & $\mathrm{R}=0.916$ & $\mathrm{R}=0.729$ & $\mathrm{R}=0.697$ & $\mathrm{R}=-0.589$ & $\mathrm{R}=-0.559$ & $\mathrm{R}=-0.428$ \\
\hline & & $\mathrm{p}<0.001$ & $\mathrm{p}<0.001$ & $\mathrm{p}<0.001$ & $\mathrm{p}<0.001$ & $\mathrm{p}<0.001$ & $\mathrm{p}<0.001$ \\
\hline & & IL-1 $\beta$ & $\mathrm{R}=0.735$ & $\mathrm{R}=0.690$ & $\mathrm{R}=-0.331$ & $\mathrm{R}=-0.294$ & $\mathrm{R}=-0.243$ \\
\hline & & & $\mathrm{p}<0.001$ & $\mathrm{p}<0.001$ & $\mathrm{p}<0.001$ & $\mathrm{p}=0.003$ & $\mathrm{p}=0.015$ \\
\hline & & & Latent anxiety & $\mathrm{R}=0.879$ & NS & NS & NS \\
\hline & & & & $\mathrm{p}<0.001$ & & & \\
\hline & & & & Apparent anxiety & NS & NS & $\mathrm{R}=-0.203$ \\
\hline & & & & & & & $\mathrm{p}=0.042$ \\
\hline & & & & & LMP & $\mathrm{R}=0.944$ & $\mathrm{R}=0.778$ \\
\hline & & & & & & $\mathrm{p}<0.001$ & $\mathrm{p}<0.001$ \\
\hline & & & & & & Baby weight & $\mathrm{R}=0.756$ \\
\hline & & & & & & & $\mathrm{p}<0.001$ \\
\hline
\end{tabular}

LMP: last menstrual period, NS: not significant

Table 3. Correlation analysis between SKA2 expression and other variables in preterm group

\begin{tabular}{|c|c|c|c|c|c|c|c|}
\hline SKA2 & Cortisol & IL-1 $\beta$ & Latent anxiety & Apparent anxiety & LMP & Baby weight & APGAR \\
\hline \multirow[t]{14}{*}{ SKA2 } & $\mathrm{R}=0.835$ & $\mathrm{R}=0.827$ & $\mathrm{R}=0.669$ & $\mathrm{R}=0.644$ & $\mathrm{R}=-0.421$ & $\mathrm{R}=-0.419$ & NS \\
\hline & $\mathrm{p}<0.001$ & $\mathrm{p}<0.001$ & $\mathrm{p}<0.001$ & $\mathrm{p}<0.001$ & $\mathrm{p}=0.003$ & $\mathrm{p}=0.003$ & \\
\hline & Cortisol & $\mathrm{R}=0.913$ & $\mathrm{R}=0.694$ & $\mathrm{R}=0.698$ & $\mathrm{R}=-0.527$ & $\mathrm{R}=-0.520$ & NS \\
\hline & & $\mathrm{p}<0.001$ & $\mathrm{p}<0.001$ & $\mathrm{p}<0.001$ & $\mathrm{p}<0.001$ & $\mathrm{p}<0.001$ & \\
\hline & & IL- $1 \beta$ & $\mathrm{R}=0.650$ & $\mathrm{R}=0.663$ & $R=-0.540$ & $\mathrm{R}=-0.532$ & $\mathrm{R}=-0.327$ \\
\hline & & & $\mathrm{p}<0.001$ & $\mathrm{p}<0.001$ & $\mathrm{p}<0.001$ & $\mathrm{p}<0.001$ & $\mathrm{p}=0.022$ \\
\hline & & & Latent anxiety & $\mathrm{R}=0.906$ & $\mathrm{R}=-0.398$ & $\mathrm{R}=-0.408$ & $\mathrm{R}=-0.324$ \\
\hline & & & & $\mathrm{p}<0.001$ & $\mathrm{p}=0.005$ & $\mathrm{p}=0.004$ & $\mathrm{p}=0.023$ \\
\hline & & & & Apparent anxiety & $\mathrm{R}=-0.418$ & $\mathrm{R}=-0.443$ & $\mathrm{R}=-0.351$ \\
\hline & & & & & $\mathrm{p}=0.003$ & $\mathrm{p}=0.001$ & $\mathrm{p}=0.014$ \\
\hline & & & & & LMP & $\mathrm{R}=0.957$ & $\mathrm{R}=0.704$ \\
\hline & & & & & & $\mathrm{p}<0.001$ & $\mathrm{p}<0.001$ \\
\hline & & & & & & Baby weight & $\mathrm{R}=0.722$ \\
\hline & & & & & & & $\mathrm{p}<0.001$ \\
\hline
\end{tabular}

LMP: last menstrual period, NS: not significant

Table 4. Correlation analysis between SKA2 expression and other variables in term group

\begin{tabular}{|c|c|c|c|c|c|c|}
\hline & Cortisol & IL-1 $\beta$ & Latent anxiety & Apparent anxiety & Baby weight & APGAR \\
\hline \multirow[t]{9}{*}{ SKA2 } & NS & NS & NS & NS & NS & NS \\
\hline & Cortisol & $\mathrm{R}=0.895$ & $\mathrm{R}=0.812$ & $\mathrm{R}=0.700$ & NS & NS \\
\hline & & $\mathrm{p}<0.001$ & $\mathrm{p}<0.001$ & $\mathrm{p}<0.001$ & & \\
\hline & & IL-1 $\beta$ & $\mathrm{R}=0.831$ & $\mathrm{R}=0.718$ & NS & NS \\
\hline & & & $\mathrm{p}<0.001$ & $\mathrm{p}<0.001$ & & \\
\hline & & & Latent anxiety & $\mathrm{R}=0.857$ & NS & NS \\
\hline & & & & $\mathrm{p}<0.001$ & & \\
\hline & & & & Apparent anxiety & NS & NS \\
\hline & & & & & Baby weight & NS \\
\hline
\end{tabular}

NS: not significant 


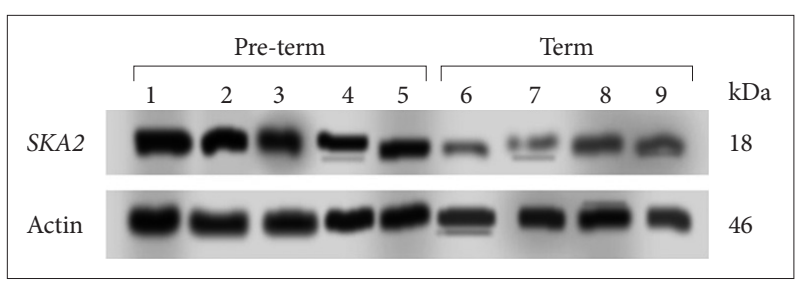

Figure 2. Representative Western blots showing the immune labeling of spindle and kinetochore associated complex subunit 2 (SKA2) and beta-actin in the membrane fraction of 2 groups: preterm labor, term labor. No. 1 to 5 is related to preterm delivery, with cortisol levels of $469,335,425,341$, and 388 , respectively. Numbers 6 to 9 are related to term delivery, with cortisol levels $282,268,318$, and 299 , respectively.

Table 5. Comparison of protein SKA2 synthesis between preterm and term groups

\begin{tabular}{llcc}
\hline & Groups & Mean \pm SD & p value \\
\hline Protein SKA2 & Preterm & $1.18 \pm 0.16$ & 0.008 \\
& Term & $0.63 \pm 0.28$ & \\
\hline
\end{tabular}

SD: standard deviation

sion, preeclampsia, and growth restriction during gestation period. ${ }^{35-38}$ The prevalence of anxiety in gestation period varies in different populations. An epidemiological study indicated that the incidence of anxiety in pregnant women was $20 \%$ in Pakistan, while it was $11 \%$ in South Africa. The severity of anxiety is a spectrum from the moderate to low grades in pregnant women..$^{39}$ In a study performed by Shapiro et al., ${ }^{40}$ it was shown that premature birth was linked with the stress-related infections, but did not correlate with mental stress. In line with this, Ravid et al. ${ }^{41}$ demonstrated that anxiety was not associated with pregnancy complications. Contrarily, Ding et al. ${ }^{38}$ showed that maternal anxiety has a strong linkage with preterm delivery.

It seems that biological studies are warranted to elucidate the association of anxiety with premature birth. In accordance with our results, the mean trait anxiety was partially higher in women with preterm delivery in comparison with those with term delivery. The current study results include maternal anxiety which has a significant positive correlation with SKA2 expression, cortisol concentration, and IL-1 $\beta$ concentration. As well as, these mentioned factors have significant negative correlation with LMP, AGPAR and baby weight. From these results, it can be concluded that anxiety, the expression of SKA2 gene, and the production of cortisol and IL-1 $\beta$ were correlated to the pregnancy period and the weight of infants.

A study carried out by Giurgescu; ${ }^{42}$ revealed that anxiety and mental stress in pregnant women, as a consequence of increased levels of cortisol, could result in premature birth. Notably, preterm delivery is associated with the early increase in $\mathrm{CRH}^{41}$ Besides, elevated levels of $\mathrm{CRH}$ can increase the concentration of cortisol and estrogen. Heightened ratios of estrogen to progesterone may disturb the uterus tranquility, which could in- crease the risk of premature birth. An early increase in cortisol can increase the uterus contraction and subsequently cause premature birth mediated by the production of prostaglandins (as an uterotonins). ${ }^{43}$ Our data indicated that an increase in the levels of cortisol results in a reduction in birth weight and LMP, considering that the levels of cortisol were elevated in women with preterm delivery compared with term delivery group.

It has been implicated that $S K A 2$ protein is able to increase the levels of glucocorticoids via chaperoning the glucocorticoid receptors and transporting them from the cytoplasm into the nucleus. ${ }^{29}$ In 2016, Boks et al..$^{44}$ reported that the rate of SKA2 gene methylation is reduced in patients with stress disorders, which is eventually resulted in an increase in the levels of cortisol. Also, Ijabi et al. ${ }^{31}$ carry out a study which has evaluated SKA2 gene SNP (NC_000017.11: g.59110368 G > A) as a predictive biomarker for the prediction of preterm delivery. In the present study, SKA2, at the level of protein and gene expression, was significantly elevated in premature birth compared with term delivery. There were significant positive correlations between the $S K A 2$ gene expression and other variables (cortisol, IL-1 $\beta$ and anxiety) in all participants (Table 2). Our findings indicated that the increased expression of SKA2 results in decreased LMP, APGAR, and birth weight in preterm group (Table 2) but not in term group (Table 3). Following an increase in the expression of $S K A 2$ gene, the concentration of the corresponding protein would be increased and we also have shown that SKA2 protein is higher in women with preterm birth than term.

In 2012, Christian ${ }^{45}$ demonstrated that chronic mental stress has detrimental effects on cell-mediated immunity, which could be resulted in serious complications. Fast et al. ${ }^{46}$ showed that increased levels of cortisol could elevate the concentrations of IL-1 $\beta$ in Salmon fish. Prinz et al..$^{22}$ in a study, evaluate the influencing factors such as stress, cortisol, and IL-1 $\beta$ in healthy aged people. They highlighted that an increase in cortisol could result in elevated levels of IL- $1 \beta$ secretion. There is still ambiguity on how glucocorticoids can shift the balance in favor of either inflammatory or anti-inflammatory responses. In this context, Straub and Cutolo ${ }^{21}$ showed that chronic increase of glucocorticoids in blood circulation could increase inflammation in patients, making them obliged to use immunosuppressive/immunomodulatory agents to quench the elevated inflammatory reactions. Cytokines, produced in the decidua, increase the secretion of uterotonins such as prostaglandins and they are capable of initiating the uterus contraction. A number of studies demonstrated that anti-inflammatory compounds play an axial role in the prevention of premature birth. It has been reported that elevated levels of prostaglandins would increase the risk of premature birth..$^{47,48} \mathrm{~A}$ higher degree of cell death and apoptotic index was observed in pregnant women PROM 
when compared with those with term delivery. It has been shown that TNF- $\alpha$ and IL- $1 \beta$ play a regulatory role in apoptosis. Moreover, increased amounts of cytokines bring about the elevation in metalloproteases and deformation in collagen. ${ }^{49}$ In line with previous studies, we showed that the levels of IL$1 \beta$ were significantly higher in preterm delivery in comparison with term delivery (Figure 1) and also indicated that IL-1 $\beta$ had a significant inverse correlation with LMP, APGAR, and birth weight. Our current results show that there is a direct relationship between the expression of $S K A 2$ and each earlymentioned factors such as cortisol, IL- $1 \beta$, and anxiety in preterm women. The over-expression of the SKA2 gene can result in the elevation of IL-1 $\beta$ and the risk of preterm delivery by increasing the levels of cortisol. Understanding the biological pathways involved in anxiety could shed light on the role of chronic stress in the increase of the levels of cortisol and IL-1 $\beta$, which indirectly predispose pregnant women to develop premature birth.

The present investigation has the following limitations: the lack of evaluation of molecular signaling pathways, failure to follow the participants in subsequent pregnancies as well as the low sample size. Furthermore, we evaluated the relation of SKA2 to IL-1 $\beta$ in preterm delivery for the first time that it was the strengths of the study. According to our findings, we suggest further studies are warranted to illuminate the role of SKA2 gene in preterm delivery.

In conclusion, the results revealed that the SKA2 gene expression was significantly higher in preterm delivery compared with pregnant women with term delivery. Additionally, the correlation analysis showed that increased expression of SKA2 in the preterm group was positively correlated with cortisol, IL-1 $\beta$, and anxiety while in the term group, such correlations were non-significant. According to the results obtained in the present study, it can be inferred that perhaps, SKA2 gene could trough increasing of cortisol and IL- $1 \beta$ level lead to preterm delivery.

\section{Acknowledgments}

This report pertained to an MSc thesis and was supported and funded by Counseling and Reproductive Health Research Centre, Golestan University of Medical Sciences, Gorgan, Iran (Grant No. 92158104).

\section{Conflicts of Interest}

The authors have no potential conflicts of interest to disclose.

\section{Author Contributions}

Conceptualization: Janat Ijabi, Roghayeh Ijabi. Data curation: Roghayeh Ijabi. Formal analysis: Hemen Moradi-Sardareh. Funding acquisition: Roghayeh Ijabi. Investigation: all authors. Methodology: Hemen MoradiSardareh, Janat Ijabi, Reza Afrisham, Roghayeh Ijabi. Projectadministration: Janat Ijabi, Roghayeh Ijabi. Resources: Janat Ijabi, Roghayeh Ijabi, Parisa Roozehdar. Software: Reza Afrisham, Janat Ijabi, Roghayeh Ijabi, Hemen Moradi-Sardareh. Supervision: Roghayeh Ijabi. Validation: Janat
Ijabi, Roghayeh Ijabi. Visualization: Janat Ijabi, Roghayeh Ijabi. Writingoriginal draft: all authors. Writing_review \& editing: Hemen MoradiSardareh, Janat Ijabi, Reza Afrisham, Roghayeh Ijabi.

\section{ORCID iDs}

Janat Ijabi

Reza Afrisham

Hemen Moradi-Sardareh

Parisa Roozehdar

Fatemeh Seifi

Roghayeh Ijabi

\section{REFERENCES}

1. Moghadami N, Aminikhah B, Tanha FD. The effect of maternal body mass index on spontaneous versus induced preterm birth: a prospective study. Tehran Univ Med J 2009;67:221-225.

2. Field D, Boyle E, Draper E, Evans A, Johnson S, Khan K, et al. The Late And Moderately Preterm Birth Study. In: Little P, Editor. Towards Reducing Variations in Infant Mortality and Morbidity: A PopulationBased Approach. Programme Grants Appl Res 2016, p.37-144.

3. McLean M, Bisits A, Davies J, Woods R, Lowry P, Smith R. A placental clock controlling the length of human pregnancy. Nat Med 1995;1: 460-463.

4. Wadhwa PD, Garite TJ, Porto M, Glynn L, Chicz-DeMet A, DunkelSchetter C, et al. Placental corticotropin-releasing hormone (CRH), spontaneous preterm birth, and fetal growth restriction: a prospective investigation. Am J Obstet Gynecol 2004;191:1063-1069.

5. Hobel CJ, Dunkel-Schetter C, Roesch SC, Castro LC, Arora CP. Maternal plasma corticotropin-releasing hormone associated with stress at 20 weeks' gestation in pregnancies ending in preterm delivery. Am J Obstet Gynecol 1999;180:S257-S263.

6. Murphy BEP. Human fetal serum cortisol levels related to gestational age: evidence of a midgestational fall and a steep late gestational rise, independent of sex or mode of delivery. Am J Obstet Gynecol 1982;144: 276-282.

7. Glynn LM, Schetter CD, Hobel CJ, Sandman CA. Pattern of perceived stress and anxiety in pregnancy predicts preterm birth. Health Psychol 2008;27:43.

8. Mancuso RA, Schetter CD, Rini CM, Roesch SC, Hobel CJ. Maternal prenatal anxiety and corticotropin-releasing hormone associated with timing of delivery. Psychosom Med 2004;66:762-769.

9. Dayan J, Creveuil C, Herlicoviez M, Herbel C, Baranger E, Savoye C, et al. Role of anxiety and depression in the onset of spontaneous preterm labor. Am J Epidemiol 2002;155:293-301.

10. Sandman CA, Glynn L, Schetter CD, Wadhwa P, Garite T, ChiczDeMet A, et al. Elevated maternal cortisol early in pregnancy predicts third trimester levels of placental corticotropin releasing hormone (CRH): priming the placental clock. Peptides 2006;27:1457-1463.

11. Fan F, Zou Y, Zhang Y, Ma X, Zhang J, Liu C, et al. The relationship between maternal anxiety and cortisol during pregnancy and birth weight of chinese neonates. BMC Pregnancy Childbirth 2018;18:265.

12. Berkowitz GS, Lapinski RH, Lockwood CJ, Florio P, Blackmore-Prince C, Petraglia F. Corticotropin-releasing factor and its binding protein: maternal serum levels in term and preterm deliveries. Am J Obstet Gynecol 1996;174:1477-1483.

13. King BR, Smith R, Nicholson RC. The regulation of human corticotrophin-releasing hormone gene expression in the placenta. Peptides 2001;22:795-801.

14. Robinson BG, Emanuel RL, Frim DM, Majzoub JA. Glucocorticoid stimulates expression of corticotropin-releasing hormone gene in human placenta. Proc Natl Acad Sci U S A 1988;85:5244-5248.

15. Power ML, Schulkin J. Functions of corticotropin-releasing hormone in anthropoid primates: from brain to placenta. Am J Human Biol 2006;18:431-447. 
16. Karalis K, Goodwin G, Majzoub JA. Cortisol blockade of progesterone: a possible molecular mechanism involved in the initiation of human labor. Nat Med 1996;2:556-560.

17. Karalis K, Majzoub JA. Regulation of placental corticotropin-releasing hormone by steroids. Ann N Y Acad Sci 1995;771:551-555.

18. Marinoni E, Korebrits C, Di Iorio R, Cosmi EV, Challis JR. Effect of betamethasone in vivo on placental corticotropin-releasing hormone in human pregnancy. A Am J Obstet Gynecol 1998;178:770-778.

19. Jones S, Brooks A, Challis J. Steroids modulate corticotropin-releasing hormone production in human fetal membranes and placenta. J Clin Endocrinol Metab 1989;68:825-830.

20. Sippell WG, Becker H, Versmold HT, Bidlingmaier F, Knorr D. Longitudinal studies of plasma aldosterone, corticosterone, deoxycorticosterone, progesterone, 17-hydroxyprogesterone, cortisol, and cortisone determined simultaneously in mother and child at birth and during the early neonatal period. I. spontaneous delivery. J Clin Endocrinol Metab 1978;46:971-985.

21. Straub RH, Cutolo M. Glucocorticoids and chronic inflammation. Rheumatology (Oxford) 2016;55(suppl 2):ii6-iil4.

22. Prinz PN, Bailey SL, Woods DL. Sleep impairments in healthy seniors: roles of stress, cortisol, and interleukin-1 beta. Chronobiol Int 2000; 17:391-404.

23. Lorenz E, Hallman M, Marttila R, Haataja R, Schwartz DA. Association between the Asp299Gly polymorphisms in the Toll-like receptor 4 and premature births in the Finnish population. Pediatr Res 2002; 52:373-376.

24. Montalbano AP, Hawgood S, Mendelson CR. Mice deficient in surfactant protein A (SP-A) and SP-D or in TLR2 manifest delayed parturition and decreased expression of inflammatory and contractile genes. Endocrinology 2013;154:483-498.

25. Youssef RE, Ledingham MA, Bollapragada SS, O'Gorman N, Jordan F, Young A, et al. The role of toll-like receptors (TLR-2 and-4) and triggering receptor expressed on myeloid cells 1 (TREM-1) in human term and preterm labor. Reprod Sci 2009;16:843-856.

26. Kacerovsky M, Vavrova J, Musilova I, Lesko D, Flidrova E, Andrys C, et al. Umbilical cord blood levels of cortisol and dehydroepiandrosterone sulfate in preterm prelabor rupture of membrane pregnancies complicated by the presence of histological chorioamnionitis. J Matern Fetal Neonatal Med 2012;25:1889-1894.

27. Vadillo-Ortega F, Estrada-Gutiérrez G. Role of matrix metalloproteinases in preterm labour. BJOG 2005;112(Suppl 1):19-22.

28. MacIntyre DA, Lee YS, Migale R, Herbert BR, Waddington SN, Peebles $\mathrm{D}$, et al. Activator protein 1 is a key terminal mediator of inflammation-induced preterm labor in mice. FASEB J 2014;28:2358-2368.

29. Rice L, Waters CE, Eccles J, Garside H, Sommer P, Kay P, et al. Identification and functional analysis of SKA2 interaction with the glucocorticoid receptor. J Endocrinol 2008;198:499-509.

30. Sadeh N, Spielberg JM, Logue MW, Wolf EJ, Smith AK, Lusk J, et al. SKA2 methylation is associated with decreased prefrontal cortical thickness and greater PTSD severity among trauma-exposed veterans. Mol Psychiatry 2016;21:357-363.

31. Ijabi J, Moradi-Sardareh H, Afrisham R, Seifi F, Ijabi R. SKA2 gene-A novel biomarker for latent anxiety and preterm birth prediction. Eur J Obstet Gynecol Reprod Biol 2019;237:106-112.

32. Magalhães RC, Moreira JM, Vieira ÉLM, Rocha NP, Miranda DM, Simões e Silva AC. Urinary levels of IL-1 $\beta$ and GDNF in preterm neonates as potential biomarkers of motor development: a prospective study. Mediators Inflamm 2017;2017:8201423.

33. Barlik M, Mrozikiewicz AE, Drews-Piasecka E, Kurzawinska G, Malews$\mathrm{ki} Z$, Drews K. The relevance of IL-1 $\beta$ and IL-1RN gene polymorphisms in the etiology of preterm delivery in the population of Polish women. Ginekol Pol 2019;90:212-216.

34. Mahram B. The Normative of Spielberger Anxiety Test in Mashhad City. Thesis of Module and Evaluation in Psychology. Mashhad: Psychology College Allameh Tabatabaie University; 2000.

35. Latendresse $\mathrm{G}$. The interaction between chronic stress and pregnancy: preterm birth from a biobehavioral perspective. J Midwifery Womens Health 2009;54:8-17.

36. Staneva A, Bogossian F, Pritchard M, Wittkowski A. The effects of maternal depression, anxiety, and perceived stress during pregnancy on preterm birth: a systematic review. Women Birth 2015;28:179-193.

37. Glover V. Maternal depression, anxiety and stress during pregnancy and child outcome; what needs to be done. Best Pract Res Clin Obstet Gynaecol 2014;28:25-35.

38. Ding XX, Wu YL, Xu SJ, Zhu RP, Jia XM, Zhang SF, et al. Maternal anxiety during pregnancy and adverse birth outcomes: a systematic review and meta-analysis of prospective cohort studies. J Affect Disord 2014;159:103-110.

39. Silva MMdJ, Nogueira DA, Clapis MJ, Leite EPRC. Anxiety in pregnancy: prevalence and associated factors. Revista da Escola de Enfermagem da USP 2017;51:e03253.

40. Shapiro GD, Fraser WD, Frasch MG, Séguin JR. Psychosocial stress in pregnancy and preterm birth: associations and mechanisms. J Perinat Med 2013;41:631-645.

41. Ravid E, Salzer L, Arnon L, Eisner M, Wiznitzer A, Weller A, et al. Is there an association between maternal anxiety propensity and pregnancy outcomes? BMC Pregnancy Childbirth 2018;18:287.

42. Giurgescu C. Are maternal cortisol levels related to preterm birth? J Obstet Gynecol Neonatal Nurs 2009;38:377-390.

43. Kalantaridou S, Zoumakis E, Makrigiannakis A, Lavasidis L, Vrekoussis T, Chrousos G. Corticotropin-releasing hormone, stress and human reproduction: an update. J Reprod Immunol 2010;85:33-39.

44. Boks MP, Rutten BP, Geuze E, Houtepen LC, Vermetten E, Kaminsky Z, et al. SKA2 methylation is involved in cortisol stress reactivity and predicts the development of post-traumatic stress disorder (PTSD) after military deployment. Neuropsychopharmacology 2016;41:1350-1356.

45. Christian LM. Physiological reactivity to psychological stress in human pregnancy: current knowledge and future directions. Prog Neurobiol 2012;99:106-116.

46. Fast MD, Hosoya S, Johnson SC, Afonso LO. Cortisol response and immune-related effects of Atlantic salmon (Salmo salar Linnaeus) subjected to short-and long-term stress. Fish Shellfish Immunol 2008;24: 194-204.

47. Sykes L, MacIntyre DA, Teoh T Bennett P. Anti-inflammatory prostaglandins for the prevention of preterm labour. Reproduction 2014: REP-13-0587.

48. Christiaens I, Zaragoza DB, Guilbert L, Robertson SA, Mitchell BF Olson DM. Inflammatory processes in preterm and term parturition. J Reprod Immunol 2008;79:50-57.

49. Kumar D, Fung W, Moore RM, Pandey V, Fox J, Stetzer B, et al. Proinflammatory cytokines found in amniotic fluid induce collagen remodeling, apoptosis, and biophysical weakening of cultured human fetal membranes. Biol Reprod 2006;74:29-34. 